\title{
KUALITAS KERUPUK SUSU \\ YANG DIBUAT DENGAN PERBEDAAN JENIS TEPUNG
}

\author{
R. A. Rihastuti' dan Nurliyani ${ }^{1}$
}

\section{INTISARI}

Lima jenis kerupuk susu dibuat dengan menggunakan bahan susu segar sebanyak 101 yang dibagi menjadi lima bagian, untuk dicampur dengan lima jenis tepung yaitu 1) tepung beras, 2) tepung terigu, 3) tepung tapioka, 4) tepung sagu dan 5) campuran dari ke-empat macam tepung tersebut dengan perbandingan 1:1:1:1. Masing-masing bagian kemudian dibagi menjadi dua perlakuan untuk diberi perlakuan yang berbeda, yaitu: a) tanpa soda kue dan b) dengan soda kue. Masing-masing jenis kerupuk ini dianalisis kualitasnya, yaitu: uji pengembangan dan uji kimia yang meliputi analisis kadar protein, lemak, kadar air dan abu yang dilakukan pada adonan dan kerupuk. Data yang diperoleh dianalisis dengan analisis varians faktorial 2 X 2 X 5 (adonan dan kerupuk, tanpa dan dengan soda kue serta lima macam tepung. Kerupuk susu yang diperoleh dengan pengeringan matahari cukup baik karena kadar air kerupuk yang diperoleh sekitar 10,93 sampai 14,99\%. Pembuatan kerupuk susu dengan soda kue cukup baik, tetapi tergantung pula pada macam tepung yang digunakan. Pengembangan yang paling baik adalah dengan tepung campuran, yaitu dapat mencapai $316,67 \%$, sedangkan dengan tepung tapioka dapat mencapai $309,22 \%$, dan dengan tepung sagu 181,29\%. Pengembangan dengan tepung beras dan tepung terigu kurang baik yaitu hanya mencapai masing-masing $19,48 \%$ dan $77,94 \%$. Kandungan protein pada kerupuk susu dengan bermacam-macam tepung dan penambahan soda kue, berbeda sesuai dengan kandungan protein pada masing-masing tepung. Kandungan protein paling tinggi adalah pada kerupuk susu dengan tepung terigu $(11,75 \%)$, sedangkan dengan tepung beras $8,81 \%$, tepung campuran $6,88 \%$, dengan tepung tapioka dan sagu kandungan proteinnya kecil yaitu 2,65\% dan 2,56\%. Pengembangan kerupuk susu terbaik diperoleh dari kerupuk susu yang dibuat dengan penambahan soda kue dan tepung campuran, kemudian dengan tepung tapioka, tetapi untuk tepung tapioka kadar proteinnya kecil.

(Kata kunci: Kualitas kerupuk susu, Jenis tepung.)

\footnotetext{
' Fakultas Peternakan UGM, Yogyakarta 55281
} 


\title{
QUALITY OF MILK CHIPS \\ USING DIFFERENT KINDS OF FLOUR
}

\begin{abstract}
Five kinds of flour were used to make five different milk chips, i. e.: 1) rice flour, 2) wheat flour, 3) cassava flour, 4) sago flour and 5) all of the four mixed in equal parts. Ten liters of milk were divided into five parts subjected to mixing with the above kinds of flour, each was then divided into two equally treated a) without and b) with sodium bicarbonate. Quality parameters analyzed were enlargement test and chemical tests of protein, fat, moisture and ash for both the doughs and chips. Analysis of variance was done using factorial design of $2 \times 2 \times 5$. The quality of sun-dried milk chip was good enough as moisture contents were ranging from 10.93 to $14.99 \%$. The use of sodium bicarbonate was effective for making better milk chips. However, it depends on the kind of flour used. The best enlargement was achieved by the use of mixed flour $(316.67 \%)$ while the uses of cassava and sago flours produced 309.22 and $181.29 \%$ enlargements, respectively. The uses of rice and wheat flours did not produce good milk chips, since the enlargements were only 19.48 and $77.94 \%$, respectively. The protein contents varied depending on the kind of flour's protein content. The highest protein content $(11.75 \%)$ was produced from the use of wheat flour, while the others were $8.81 \%$ (rice flour), $6.88 \%$ (mixed flour), $2.65 \%$ (cassava flour) and $2.56 \%$ (sago flour).
\end{abstract}

(Key words: Milk chip's quality, Kinds of flour.)

\section{Pendahuluan}

Bahan dasar susu dapat diolah menjadi bermacam-macam hasil olahan susu antara lain kerupuk susu. Kerupuk susu merupakan jenis makanan ringan yang kemungkinan disukai oleh anak dan orang dewasa. Bahan makanan yang terbuat dari bahan dasar susu mempunyai nilai gizi yang tinggi, karena mengandung protein dan vitamin yang diperlukan oleh manusia.

Pada saat ini kerupuk susu mulai dipasarkan kepada masyarakat, tetapi belum pernah diteliti mengenai kualitas kerupuk susu tersebut. Disamping itu juga belum pernah diteliti mengenai jenis tepung untuk menghasilkan kerupuk susu dengan kualitas terbaik.

Kerupuk susu adalah campuran dari susu dan tepung terigu dengan perbandingan 2,5 I susu dengan $1 \mathrm{~kg}$ tepung terigu dan $50 \mathrm{~g}$ garam bleng (Anonimus, 1984). Kerupuk di Indonesia khususnya di Pulau Jawa terbuat dari tapioka sebagai bahan utama. (Falcon et al., 1986). Kerupuk susu kemungkinan dapat pula dibuat dengan tepung lain yang mudah didapat di Indonesia seperti tepung beras, tapioka dan sagu.
Tepung terigu, beras, tapioka dan sagu, tepung terigu mempunyai komposisi sebagai berikut; karbohidrat 65 sampai $70 \%$, protein 8 sampai $14 \%$, lemak 0,8 sampai $2 \%$ dan kadar air 11 sampai $15,5 \%$ (Potter, 1968; Anonimus, 1974; Buckle et al. 1985). Komposisi kimia padi, karbohidrat $65 \%$, protein $8 \%$, lemak $2 \%$ dan kadar air $11 \%$ (Potter, 1968).

Tepung tapioka mempunyai kompisisi sebagai berikut; kadar air $15 \%$, protein 0,5 sampai $0,7 \%$, lemak $0,2 \%$, karbohidrat $85 \%$, kadar abu $0,3 \%$ dan serat kasar $0,5 \%$ serta mempunyai kalori $307 / 100 \mathrm{~g}$ (Anonimus, 1974).

Tepung sagu mempunyai komposisi kimia sebagai berikut; protein $0,5 \%$, karbohidrat $88 \%$, dan sedikit lemak (Anonimus, 1974).

Pengeringan dengan matahari adalah salah satu cara pengawetan secara sederhana, sampai sekarang masih dilakukan dan kandungan air menjadi 14 sampai 15\% (Potter, 1968).

Pembuatan kerupuk pada umumnya dimasyarakat menggunakan garam bleng, tetapi pada penelitian ini menggunakan soda kue (sodium bicarbonate) sebagai sumber carbon dioxide.

Penggorengan, perubahan-perubahan yang terjadi selama proses penggorengan yaitu terjadinya kuali

dilak

adone

kadar

denga

pema:

diperc

dan $k$

macan

matahs

antara

cukup

(1968)

mengh

penam menunj

kadar

perbeds

yang $n$ 
penguapan air, kenaikan suhu produk yang menyebabkan terjadinya pencoklatan dan produk menjadi renyah, perubahan dimensional pada produk yang telah digoreng, pindahnya komponen-komponen minyak ke-dalam produk yang digoreng, keluarnya minyak dari bahan yang digantikan dengan masuknya minyak goreng dalam produk serta terjadinya perubahan densitas produk selama proses penggorengan (Heid dan Joslyn, 1967).

Penelitian ini bertujuan untuk mengetahui perbedaan tepung sebagai bahan campuran kerupuk susu terhadap kualitas kerupuk susu.

\section{Materi dan Metode}

Pada penelitian ini digunakan 101 susu segar, dibagi menjadi lima bagian, dicampur dengan 1) tepung beras, 2) tepung terigu, 3) tepung tapioka, 4) tepung sagu dan 5) dengan ke-empat macam tepung tersebut dengan perbandingan 1:1:1:1. Masing-masing bagian dibagi menjadi dua perlakuan yaitu tanpa dan dengan soda kue.

Masing-masing perlakuan dianalisis kualitasnya yang meliputi uji fisik pengembangan dilakukan pada kerupuk dan uji kimia dilakukan pada adonan dan pada kerupuk yang meliputi analisis kadar protein dengan metode Kjeldahl, kadar lemak dengan metode Soxhlet dan kadar air dengan cara pemanasan (Sudarmadji et al., 1984). Data yang diperoleh dianalisis dengan anava $2 \times 2 \times 5$ (adonan dan kerupuk, tanpa dan dengan soda kue dan lima macam tepung).

\section{Hasil Penelitian dan Pembahasan}

Kadar air kerupuk susu dengan pengeringan matahari pada hasil penelitian ini rata-rata berkisar antara 10,93 sampai $14,99 \%$ (Tabel 1). Hasil tersebut cukup baik karena sesuai dengan pendapat Potter (1968), bahwa pengeringan dengan sinar matahari menghasilkan kadar air antara 14 sampai $15 \%$.

Tabel 1 menunjukkan bahwa perbedaan penambahan soda kue dan tanpa soda kue menunjukkan perbedaan yang tidak nyata. Perbedaan kadar air pada adonan dan pada kerupuk serta perbedaan macam tepung menunjukkan perbedaan yang nyata dengan $P<0,01$. Pengurangan kadar air dari adonan menjadi kerupuk rata-rata adalah dari 48,04 sampai $50,83 \%$ menjadi 11,20 sampai $14,76 \%$.Kadar air pada perbedaan tepung tergantung dari jenis tepung tersebut, karena pada masing-masing tepung berbeda kadar airnya. Kadar air tepung terigu 13,0 sampai $15,5 \%$, tepung tapioka $15 \%$ dan kadar air beras 11\% (Anonimus, 1974).

Kadar lemak pada hasil penelitian ini antara perbedaan penambahan soda kue dan tanpa soda kue menunjukkan perbedaan yang tidak nyata. Kadar lemak pada adonan dan pada kerupuk serta pada perbedaan macam tepung menunjukkan perbedaan yang nyata $(\mathrm{P}<0,01)$ (Tabel 2$)$.

Perbedaan kadar lemak pada adonan dan kerupuk disebabkan karena pemanasan atau pengeringan. Rata-rata dadar lemak pada kerupuk dari tepung campuran adalah $3,41 \%$, tepung terigu $3,39 \%$, tepung tapioka $2,96 \%$, tepung beras $2,45 \%$ dan tepung sagu $1,81 \%$.

Perbedaan kadar lemak pada bermacammacam adonan disebabkan oleh kadar lemak dari masing-masing tepung yang berbeda. Kadar lemak padi lebih kurang $2 \%$ (Buckle et al., 1985), tepung terigu 0,8 sampai $1,5 \%$, tepung tapioka $0,2 \%$ dan sagu mengandung sedikit kadar lemak (Anonimus, 1974).

Rata-rata kadar lemak pada adonan dari tepung terigu dan beras hampir sama yaitu $3,19 \%$ dan $3,07 \%$, kemudian tepung tapioka $2,42 \%$, tepung campuran $2,27 \%$ dan paling kecil kadar lemak pada adonan dari tepung sagu $1,96 \%$.

Kadar protein pada hasil penelitian ini dengan penambahan dan tanpa penambahan soda kue menunjukkan perbedaan yang tidak nyata. Kadar protein pada adonan dan pada kerupuk menunjukkan perbedaan yang nyata $(P<0,05)$.

Perbedaan macam tepung juga menunjukkan perbedaan yang nyata $(P<0,01)$ pada kadar protein kerupuk susu (Tabel 3 ).

Perbedaan macam tepung pada pembuatan kerupuk susu menyebabkan kandungan protein pada adonan dan kerupuk susu berbeda nyata $(P<0,01)$. Kadar protein kerupuk susu dengan tepung terigu paling tinggi yaitu rata-rata $12,59 \%$ pada adonan dan $11,99 \%$ pada kerupuk, yang disebabkan oleh kadar protein terigu yang juga tinggi yaitu sebesar 8 sampai 13\% (Anonimus, 1974). 
TABEL 1. RATA-RATA KADAR AIR PADA ADONAN DAN KERUPUK SUSU DENGAN BERMACAM-MACAM TEPUNG, TANPA DAN DENGAN PENAMBAHAN SODE KUE

\begin{tabular}{lllllll}
\hline \hline & \multicolumn{2}{c}{ Adonan } & \multicolumn{3}{c}{ Kerupuk } \\
& $\begin{array}{l}\text { Tanpa } \\
\text { Soda kue }\end{array}$ & $\begin{array}{l}\text { Dengan } \\
\text { Soda kue }\end{array}$ & $\begin{array}{l}\text { Rata- } \\
\text { rata }\end{array}$ & $\begin{array}{l}\text { Tanpa } \\
\text { Soda kue }\end{array}$ & $\begin{array}{l}\text { Dengan } \\
\text { Soda kue }\end{array}$ & $\begin{array}{l}\text { Rata- } \\
\text { rata }\end{array}$ \\
\hline T. Beras & 47,67 & 48,40 & $48,04^{\circ}$ & 10,93 & 11,48 & $11,20^{\mathrm{d}}$ \\
T. Terigu & 49,22 & 49,71 & $49,47^{\mathrm{b}}$ & 13,11 & 12,31 & $12,71^{\mathrm{e}}$ \\
T. Tapioka & 48,99 & 49,39 & $49,19^{\mathrm{b}}$ & 11,76 & 13,75 & $12,50^{\mathrm{e}}$ \\
T. Sagu & 49,51 & 48,34 & $48,93^{\mathrm{a}, \mathrm{b}}$ & 11,97 & 12,66 & $12,07^{\mathrm{d}, \mathrm{e}}$ \\
T. Campuran & 50,50 & 51,16 & $50,83^{\mathrm{c}}$ & 14,99 & 14,53 & $14,76^{\mathrm{f}}$ \\
\hline Rata-rata & $49,18^{\mathrm{s}}$ & $49,40^{\mathrm{a}}$ & & $12,55^{\mathrm{h}}$ & $12,74^{\mathrm{h}}$ & \\
\hline
\end{tabular}

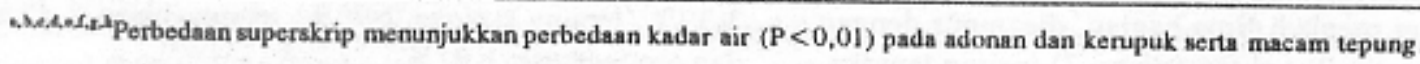

TABEL 2. RATA-RATA KADAR LEMAK DALAM BAHAN KERING PADA ADONAN DAN KERUPUK SUSU DENGAN BERMACAM-MACAM TEPUNG, TANPA DAN DENGAN PENAMBAHAN SODA KUE (\%)

\begin{tabular}{lllllll}
\hline \hline & \multicolumn{2}{c}{ Adonan } & \multicolumn{3}{c}{ Kerupuk } \\
\hline & $\begin{array}{l}\text { Tanpa } \\
\text { Soda kue }\end{array}$ & $\begin{array}{l}\text { Dengan } \\
\text { Soda kue }\end{array}$ & $\begin{array}{l}\text { Rata- } \\
\text { rata }\end{array}$ & $\begin{array}{l}\text { Tanpa } \\
\text { Soda kue }\end{array}$ & $\begin{array}{l}\text { Dengan } \\
\text { Soda kue }\end{array}$ & $\begin{array}{l}\text { Rata- } \\
\text { rata }\end{array}$ \\
\hline T. Beras & 2,82 & 3,32 & $3,07^{\mathrm{a}}$ & 2,49 & 2,40 & $2,45^{\text {d }}$ \\
T. Terigu & 3,11 & 3,27 & $3,19^{\mathrm{a}}$ & 3,20 & 3,59 & $3,39^{\circ}$ \\
T. Tapioka & 2,70 & 2,14 & $2,42^{\mathrm{b}}$ & 3,35 & 2,57 & $2,96^{\mathrm{a}, \mathrm{b}}$ \\
T. Sagu & 2,06 & 1,86 & $1,96^{\mathrm{a}}$ & 1,91 & 1,70 & $1,81^{\mathrm{e}}$ \\
T. Campuran & 2,44 & 2,10 & $2,27^{\mathrm{b}, \mathrm{e}}$ & 2,95 & 3,88 & $3,41^{*}$ \\
\hline Rata-rata & 2,63 & 2,54 & & 2,78 & 2,83 & \\
\hline
\end{tabular}

-bed Perpedana superakrip menunjukkan perbedaan kadar lemak $(P<0,01)$ pada adonan dan kerupuk serta macam tepung.

Kerupuk susu dengan tepung beras juga mempunyai protein yang tinggi yaitu rata-rata $9,57 \%$ pada adonan dan $8,66 \%$ pada kerupuk, sedangkan protein beras sekitar $8 \%$ (Anonimus, 1974). Kerupuk susu dengan tepung tapioka dan tepung sagu kandungan proteinnya kecil dikarenakan kandungan protein dalam tepung tapioka dan tepung sagu juga kecil yaitu 0,5 sampai $0,7 \%$ dan $0,5 \%$ (Anonimus, 1974).
Rata-rata kadar protein adonan menjadi kerupuk susu mengalami penurunan dengan nyata $(\mathrm{P}<0,05)$, dari $7,25 \%$ menjadi $6,79 \%$ pada kerupuk susu tanpa soda kue dan 7,53\% menjadi $6,53 \%$ pada kerupuk susu dengan șoda kue.

Pengembangan kerupuk susu, dari sebelum dimasak, kemudian dimasak adalah sangat nyata $(P<0,01)$ (Tabel 4). Pengembangan paling baik 
TABEL 3. RATA-RATA KADAR PROTEIN PADA ADONAN DAN KERUPUK SUSU DENGAN BERMACAM-MACAM TEPUNG, TANPA DAN DENGAN PENAMBAHAN SODA KUE (\%)

\begin{tabular}{lcccccc}
\hline \hline & \multicolumn{2}{c}{ Adonan } & \multicolumn{3}{c}{ Kerupuk } \\
& $\begin{array}{l}\text { Tanpa } \\
\text { Soda kue }\end{array}$ & $\begin{array}{l}\text { Dengan } \\
\text { Soda kue }\end{array}$ & $\begin{array}{l}\text { Rata- } \\
\text { rata }\end{array}$ & $\begin{array}{l}\text { Tanpa } \\
\text { Soda kue }\end{array}$ & $\begin{array}{l}\text { Dengan } \\
\text { Soda kue }\end{array}$ & $\begin{array}{l}\text { Rata- } \\
\text { rata }\end{array}$ \\
\hline T. Beras & 9,53 & 9,61 & $9,57^{\circ}$ & 8,50 & 8,81 & $8,66^{\mathrm{c}}$ \\
T. Terigu & 12,15 & 13,03 & $12,59^{\mathrm{b}}$ & 12,24 & 11,75 & $11,99^{\mathrm{b}}$ \\
T. Tapioka & 3,13 & 3,65 & $3,39^{\mathrm{b}}$ & 2,59 & 2,65 & $2,62^{\mathrm{f}}$ \\
T. Sagu & 4,54 & 3,98 & $4,26^{\circ}$ & 2,86 & 2,56 & $2,71^{\mathrm{f}}$ \\
T. Campuran & 6,92 & 7,39 & $7,15^{\mathrm{d}}$ & 7,78 & 6,88 & $7,33^{\mathrm{d}}$ \\
\hline Rata-rata & $7,25^{\mathrm{a}}$ & $7,53^{\mathrm{b}}$ & & $6,79^{\mathrm{b}}$ & $6,53^{\mathrm{h}}$ & \\
\hline
\end{tabular}

w.he.A,a,ta, Perbedaan superakrip menunjukkan perbedaan kadar protein $(\mathrm{P}<0,05)$ pada adonan dan kerupuk serta macam tepung (P,0,01).

TABEL 4. RATA-RATA PENGEMBANGAN KERUPUK SUSU DENGAN BERMACAM-MACAM TEPUNG TANPA DAN DENGAN PENAMBAHAN SODA KUE (\%)

\begin{tabular}{lccc}
\hline \hline & $\begin{array}{l}\text { Tanpa } \\
\text { Soda kue }\end{array}$ & $\begin{array}{l}\text { Dengan } \\
\text { Soda kue }\end{array}$ & $\begin{array}{l}\text { Rata- } \\
\text { rata }\end{array}$ \\
\hline T. Beras & $15,32^{\mathrm{t}}$ & $19,48^{\mathrm{t}}$ & 17.40 \\
T. Terigu & $50,10^{\mathrm{b}}$ & $77,94^{\mathrm{a}}$ & 64,02 \\
T. Tapioka & $82,69^{\mathrm{c}}$ & $309,22^{\mathrm{h}}$ & 195,95 \\
T. Sagu & $120,9^{\mathrm{d}}$ & $181,29^{\mathrm{i}}$ & 151,13 \\
T. Campuran & $195,03^{\mathrm{e}}$ & $316,67^{\mathrm{j}}$ & 255,85 \\
\hline Rata-rata & 92,82 & 180,92 & \\
\hline
\end{tabular}

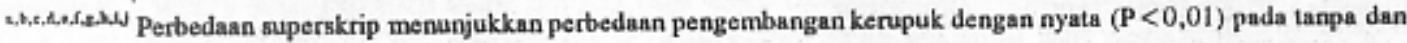
dengan aoda kue serta bermacam-macam tepung

dengan penambahan soda kue adalah pada kerupuk susu dengan tepung campuran yaitu mencapai $316,67 \%$, dengan tepung tapioka dapat mencapai rata-rata $309,22 \%$, kemudian dengan tepung tepungsagu pengembangannya $181,29 \%$. Pengembangan paling baik pada kerupuk susu tanpa penambahan soda kue adalah dengan tepung campuran yaitu sebesar $195,03 \%$, kemudian dengan tepung sagu sebesar $120,97 \%$, dengan tepung tapioka sebesar $82,69 \%$ dan dengan tepung terigu sebesar
$50,10 \%$. Pembuatan kerupuk susu dengan tepung beras baik tanpa atau dengan soda kue, pengembangannya paling kecil yaitu sebesar $15,32 \%$ dan $19,48 \%$.

Penambahan soda kue pada pembuatan kerupuk susu menyebabkan perbedaan pengembangan yang nyata $(P<0,01)$. Rata-rata pengembangan $92,82 \%$ pada tanpa penambahan soda kue dan $180,92 \%$ dengan penambahan soda kue, sehingga penggunaan soda kue pada pembuatan kerupuk susu menyebabkan pengembangan yang baik. 
Rata-rata pengembangan pada perbedaan jenis tepung berbeda nyata $(P<0,01)$. Rata-rata pengembangan paling baik adalah pada pembuatan kerupuk dengan tepung campuran $255,85 \%$, kemudian dengan tepung tapioka $195,59 \%$, tepung sagu $151,13 \%$, tepung terigu $64,02 \%$ dan paling kecil pengembangannya adalah kerupuk susu dengan tepung beras $(17,40 \%)$. Menurut Marwanto (1987) pengembangan kerupuk susu yang dibuat dengan tepung tapioka sebanyak $1 \mathrm{~kg} / 2,5$ I susu, sebesar $323,95 \%$.

\section{Kesimpulan}

Pembuatan kerupuk susu dengan sodal kue cukup baik, tetapi tergantung pula pada macam tepung yang digunakan. Pengembangan yang paling baik adalah dengan tepung campuran, pengembangan dapat mencapai $316,67 \%$, dengan tepung tapioka pengembangarnya mencapai $309,22 \%$, dengan tepung sagu mencapai $181,29 \%$. Tepung beras dan tepung terigu pengembangannya kurang baik karena hanya mencapai masing-masing $19,48 \%$ dan $77,94 \%$.

Kandungan protein pada kerupuk susu dengan bermacam-macam tepung berbeda sesuai dengan kandungan protein pada masing-masing tepung. Kandungan protein paling tinggi pada kerupuk susu dengan soda kue adalah kerupuk susu dengan tepung terigu $(11,75 \%)$, disusul kerupuk susu dengan tepung beras $(8,81 \%)$, kemudian dengan tepung campuran $(6,88 \%)$. Untuk kerupuk susu dengan tepung tapioka dan sagu dengan soda kue, kandungan porteinnya kecil yaitu $2,65 \%$ dan $2,56 \%$.

Pengembangan kerupuk susu terbaik diperoleh dari kerupuk susu yang dibuat dengan penambahan soda kue dan tepung campuran, kemudian dengan tepung tapioka, tetapi untuk tepung tapioka kandungan proteinnya kecil yaitu 2,65\%.

\section{Daftar Pustaka}

Adnan, M., 1984. Kimia dan Teknologi Pengolahan Air Susu. Cetakan ke-2, Andi Offset, Yogyakarta.

Anonimus, 1974. Encyclopaedia Britanica. William Berton Pub I is her I $943-1973$. Chicago/London/Toronto/Geneva/Sydney/Tokyo/Oran ila/Seoul.

Anonimus, 1984. Pedoman Pengolahan Susu Sederhana. Direktorat Bina Usaha Petani Ternak dan Pengolahan Hasil Peternakan, Ditjen Peternakan, Jakarta.

Buckles, K. A., R. A. Edwards, G. H. Fleet dan M. Wooton, 1985. Ibmu Pangan. Diterjemahkan oleh Purnomo, H. dan Adiono. Penerbit Universitas Indonesia, Jakarta.

Falcon, W. P., William, O. J., Scott, R. P., 1986. Ekonomi Ubikayu di P. Jawa. Diterjemahkan oleh: Suyoko, $Y$. Diterbitkan atas kerjasama Stanford University Press dengan Penerbit Sinar Harapan, Jakarta.

Heid, V. L. and M. A. Joslyn, 1967. Fundamentals of Food Processing Operation Ingredients, Methods and Packaging. The Avi Publishing Co. Ine. Westport, Connecticut.

Lampert, L. M., 1975. Modem Dairy Product. 3rd ed., Chemical Publ. Co. Inc., New York.

Marwanto, J., 1987. Substitusj tepung terigu dengan tepung tapioka pada pembuatan kerupuk susu. Teais S1, Jurusan Pengolahan Hasil Pertanian, Fakultas Teknologi Pertanian, Univeraitas Gadjah Mada.

Polter, N. N., 1968. Food Science. The Avi Publishing Co. Ine., Weatport, Connecticut.

Sudarmadji, S., B. Haryono dan Suhardi, 1984. Prosedur Analisa untuk Bahan Makanan dan Pertanian. Edisi ketiga, Penerbit Liberty, Yogyakarta. yang

kulit

dewa:

uji, s

perco

conto.

selam

kekua

denga

kimia

kelem

(Kata

male b

in whic

experir

sample

high an

12 wee

numbe

treatme

high hu

(Key w

${ }^{1}$ Fakult 